\title{
Short Communication: Correlations of Marker-Assisted Breeding Values with Progeny-Test Breeding Values for Eight Hundred Ninety-Nine French Holstein Bulls
}

\author{
F. Guillaume, ${ }^{*} \dagger^{1}$ S. Fritz, $\neq$ D. Boichard, ${ }^{*}$ and T. Druet ${ }^{*}$ \\ *INRA, UR337 Station de Génétique Quantitative et Appliquée, F-78350 Jouy en Josas, France \\ †'nstitut de l'élevage, 149 rue de Bercy, 75595 Paris Cedex 12, France \\ ¥Union nationale des coopératives d'élevage et d'insémination animale, 149 rue de Bercy, 75595 Paris Cedex 12, France
}

\begin{abstract}
French artificial insemination companies have been running a marker-assisted selection program since 2001 to determine which young bulls should be progeny tested. A first batch of 899 Holstein sires receiving their first proofs based on progeny daughters has been studied. Estimated breeding values with or without marker information were computed based on information available in April 2004, and correlated to daughter yield deviations available in 2007 for production traits. Markerassisted estimated breeding values presented greater correlations with daughter yield deviations than those calculated using only pedigree index. The average improvement in correlation was 0.043 and ranged from +0.001 for protein yield to +0.103 for fat percentage. This gain was based on the initial and suboptimal conditions of the program and is expected to increase in the coming years because of several improvements implemented since the start of the marker-assisted selection program. Key words: dairy cattle, marker-assisted selection
\end{abstract}

Over the last decade, several QTL detection programs have been conducted in dairy cattle (e.g., Georges et al., 1995; Boichard et al., 2003). Such studies revealed the existence of several QTL with large effect on dairy traits such as the gene encoding acylCoA:diacyglycerol acyltransferase (DGAT1) on chromosome 14 (Grisart et al., 2002), the ATP-binding cassette, subfamily G, member 2 gene (ABCG2) on chromosome 6 (Cohen-Zinder et al., $2005)$, or the growth hormone receptor $(G H R)$ on chromosome 20 (Blott et al., 2003). Use of these QTL in a marker-assisted selection (MAS) program has the potential to improve selection efficiency in dairy cattle (Kashi et al., 1990). Since 2001, such a MAS program has been implemented in France in the Holstein, Normande, and

Received November 5, 2007.

Accepted February 8, 2008.

${ }^{1}$ Corresponding author: Francois.Guillaume@jouy.inra.fr
Montbéliarde breeds (Boichard et al., 2002). One of the objectives of this program is to help breeding companies select which young bulls should be progeny tested. The accurate genetic value of selected animals can only be calculated after progeny testing (approximately $5 \mathrm{yr}$ after the selection decision has been made). Consequently, efficiency of the MAS program is difficult to prove on real data and can be estimated only after a few years of implementation. In January 2007, the accuracy of production traits' EBV of young bulls born in 2001 was high because of the records of their progeny daughters. These bulls were also genotyped for MAS and can therefore be used to assess the precision of MAS breeding values. The objective of this study was to check, using real data, if breeding values estimated for young animals using MAS were more precise than breeding values obtained at the same age based only on a polygenic model.

Files of the evaluation of April 2004 (the oldest conserved MAS data set) were used in this study. This evaluation used a pedigree of 34,318 animals of which 23,137 had phenotypic records and 16,629 were genotyped. Animals were genotyped for 43 microsatellite markers, which were used to follow the transmission of 14 QTL regions that relied on 2 to 5 evenly spaced microsatellite markers. These QTL were selected on basis of the results of a QTL detection program (Boichard et al., 2003) and confirmed with new sire families (Druet et al., 2006).

Phenotypic records were twice the daughter yield deviations (DYD) for males and yield deviations for females computed for milk, fat, and protein yields and fat and protein percentages, pooled from the first 3 lactations jointly as in VanRaden and Wiggans (1991). These records were obtained from the official genetic evaluations of both April 2004 and January 2007 (Robert-Granié et al., 1999). Respective weights were estimated as in VanRaden and Wiggans (1991) with a correction for number of cows in each herd.

The model used in this study was a single-trait and multiple-QTL model as proposed by Fernando and Grossman (1989): 
Table 1. Proportions of genetic variance used in the evaluation model for the QTL and polygenic effects for dairy traits and average informativity per QTL and traits (weighted by proportion of genetic variance explained) in the candidate population

\begin{tabular}{|c|c|c|c|c|c|c|c|c|c|c|}
\hline Trait & Heritability & Informativity $^{1}$ & \multicolumn{7}{|c|}{ Chromosome } & $\begin{array}{l}\text { Polygenic } \\
\text { effect, \% }\end{array}$ \\
\hline Milk yield & 0.30 & 0.57 & 0 & 0 & 5 & 15 & 0 & 10 & 10 & 60 \\
\hline Protein yield & 0.30 & 0.57 & 0 & 5 & 5 & 10 & 5 & 0 & 10 & 65 \\
\hline Fat percentage & 0.50 & 0.66 & 0 & 5 & 5 & 40 & 0 & 10 & 0 & 40 \\
\hline Protein percentage & 0.50 & 0.67 & 10 & 15 & 0 & 10 & 0 & 15 & 0 & 50 \\
\hline \multicolumn{3}{|c|}{ Informativity/chromosome $^{1}$} & 0.71 & 0.75 & 0.60 & 0.68 & 0.44 & 0.57 & 0.42 & \\
\hline
\end{tabular}

${ }^{1}$ Informativity was computed as the average of $\left|1-2 p_{i j}\right|$, where $p_{i j}$ is the probability for individual i of receiving the paternal QTL of its parent $\mathrm{j}$.

$$
\mathbf{y}=\mathbf{X} \boldsymbol{\beta}+\mathbf{Z u}+\sum_{\mathrm{i}=1}^{\mathrm{n} \_\mathrm{qtl}} \mathbf{Z}_{\mathrm{v}_{\mathrm{i}}} \mathbf{v}_{\mathrm{i}}+\mathbf{e}
$$

where $\mathbf{y}$ is a vector containing records, $\beta$ is a vector of fixed effects (the mean), $\mathbf{u}$ is a vector of random polygenic effects, $\mathbf{v}_{i}$ is a vector of random gametic effects for QTL $\mathrm{i}$, $\mathrm{n}$ qtl is the number of QTL considered for the trait, and $\mathbf{e}$ is a vector of random residual terms. $\mathbf{X}, \mathbf{Z}$, and $\mathbf{Z}_{\mathrm{v}_{\mathrm{i}}}$ are known design matrices relating results to fixed, random polygenic, and gametic effects, respectively. Probability of identity-by-descent matrices $\left(\mathbf{Z}_{\mathrm{v}_{\mathrm{i}}}\right)$ were obtained using a method similar to that of Pong-Wong et al. (2001). Between 4 and 5 QTL were used for each production trait, and the variance components (see Table 1) were assessed in a previous study (Druet et al., 2006).

A subset of 899 Holstein progeny-tested sires was used in the validation analysis. Among these genotyped candidates, a range of situations exist regarding knowledge of their ancestors' genotypes. Approximately 3 to 4 generations of sires were genotyped on the paternal path of candidates (as far as 5 generations from the candidate, more than $50 \%$ of the male ancestors are genotyped on the paternal side), whereas 0 to 2 generations of parents were genotyped on the maternal side (less than $50 \%$ of the female ancestors are genotyped after 2 generations from candidates). These candidates had no daughters with records in April 2004, whereas they had, on average, 76 daughters (SD of 16) with records in 2007. The weighted correlations between their DYD in January 2007 and both polygenic (i.e., pedigree index) and MAS EBV in 2004 (Table 2) were compared. These correla- tions were obtained for milk, fat, and protein yields and fat and protein percentages.

Correlations between DYD and pedigree index ranged from 0.317 for protein yield to 0.556 for fat content, whereas correlations between DYD and MAS EBV ranged from 0.318 for protein yield to 0.659 for fat content. The gains in correlation obtained with MAS were, on average, around 0.04 . They were lower $(0.001)$ for protein yield and greater $(0.103)$ for fat content.

A simulation study performed on the French MAS program (Guillaume et al., 2008) estimated the expected gains of correlation from MAS EBV over pedigree index and also their variation. The present results are in agreement with the results obtained by simulation: correlations are slightly lower for milk yield and protein yield and content, and greater for fat yield and percentage. The simulation study showed that these gains are expected to vary for each crop of bulls and that use of DYD instead of the unknown true genetic values underestimates the gain in accuracy achieved by MAS. Finally, Guillaume et al. (2008) indicated that the gain in accuracy achieved by MAS is clearly larger for young bulls born in 2006 than for animals born during the first years of the program. Indeed, the program is accumulating more information; approximately 10,000 new genotyped animals are integrated into the database each year. These additional genotypes improve the efficiency of the program.

To further increase the efficiency of the program, breeding companies have decided to genotype dams of young bulls and some progeny daughters of sires of

Table 2. Correlations between daughter yield deviations (DYD) of January 2007 and classical or markerassisted selection (MAS) EBV based on April 2004 evaluation of 899 progeny-tested Holstein bulls for production traits weighted by DYD reliability in 2007

\begin{tabular}{lccccc}
\hline Item & Milk & $\begin{array}{c}\text { Fat } \\
\text { yield }\end{array}$ & $\begin{array}{c}\text { Protein } \\
\text { yield }\end{array}$ & $\begin{array}{c}\text { Fat } \\
\text { percentage }\end{array}$ & $\begin{array}{c}\text { Protein } \\
\text { percentage }\end{array}$ \\
\hline EBV & 0.405 & 0.361 & 0.317 & 0.556 & 0.505 \\
MAS EBV & 0.436 & 0.400 & 0.318 & 0.659 & 0.547 \\
Difference & 0.030 & 0.039 & 0.001 & 0.103 & 0.042 \\
\hline
\end{tabular}


young bulls. This targeted genotyping has been shown to enhance the efficiency of MAS. In the batch of 899 candidates studied, only $66 \%$ of the candidates' dams were genotyped and first-crop daughter genotypes of only 6 of 39 sires were available, whereas these numbers are now much larger. Finally, the set of microsatellite markers was also changed in 2005, and the QTL are now followed with more accuracy.

In this study, the greatest increases in terms of correlation were observed for milk content traits. This can be explained by the fact that a larger proportion of the genetic variance was explained by the QTL for these traits. The lowest gain was obtained for protein yield, in which QTL explained only $35 \%$ of the genetic variation. Gains in correlation are ordered in the same way as proportion of genetic variance explained by QTL, so that the proportion of genetic variance explained by QTL should be large enough to obtain improvement of accuracy. Furthermore, content traits were influenced by QTL for which average informativity weighted by proportion of variance explained by each QTL was greater (Table 1). This is partly due to the low informativity achieved with the markers for QTL on Bos taurus autosomes 19 and 26, which influenced yield traits. To resolve this problem, new microsatellite markers were selected in 2005.

In the present data set, EBV were available only for progeny-tested bulls. Candidates not selected for progeny testing were not included in the study. These animals correspond to those candidates that had poor MAS EBV. A study including all candidates would better assess the efficiency of MAS. Unfortunately, precise genetic values based on progeny daughters are not available for unselected candidates.

In the coming years, efficiency of MAS is expected to improve because our knowledge of the genome is increasing. Methods using genetic markers in animal selection will certainly change. Indeed, future methods will use markers closer to the QTL or use the mutations directly responsible for QTL variation. Linkage disequilibrium between markers and QTL can be used in these conditions. Finally, because of the ability to genotype animals at many more markers at a reasonable cost, genomic selection (Visscher and Haley, 1998; Meuwissen et al., 2001) will be possible.

\section{ACKNOWLEDGMENTS}

The French Ministry of Agriculture is acknowledged for financial support through a CASDAR grant, and
INRA and UNCEIA are acknowledged for providing access to their data.

\section{REFERENCES}

Blott, S., J. J. Kim, S. Moisio, A. Schmidt-Küntzel, A. Cornet, P. Berzi, N. Cambiaso, C. Ford, B. Grisart, D. Johnson, L. Karim, P. Simon, R. Snell, R. Spelman, J. Wong, J. Vilkki, M. Georges, F. Farnir, and W. Coppieters. 2003. Molecular dissection of a quantitative trait locus: A phenylalanine-to-tyrosine substitution in the transmembrane domain of the bovine growth hormone receptor is associated with a major effect on milk yield and composition. Genetics 163:253-266.

Boichard, D., S. Fritz, M. N. Rossignol, M. Y. Boscher, A. Malafosse, and J. J. Colleau. 2002. Implementation of marker-assisted selection in French dairy cattle. Commun. no. 22-03 in Proc. 7th World Congr. Genet. Appl. Livest. Prod., Montpellier, France. J. M. Elsen and V. Ducrocq, ed.

Boichard, D., C. Grohs, F. Bourgeois, F. Cerqueira, R. Faugeras, A. Neau, R. Rupp, Y. Amigues, M. Y. Boscher, and H. Levéziel. 2003. Detection of genes influencing economic traits in three French dairy cattle breeds. Genet. Sel. Evol. 35:77-101.

Cohen-Zinder, M., E. Seroussi, D. M. Larkin, J. J. Loor, A. Evertsvan der Wind, J. H. Lee, J. K. Drackley, M. R. Band, A. G. Hernandez, M. Shani, H. A. Lewin, J. I. Weller, and M. Ron. 2005. Identification of a missense mutation in the bovine ABCG2 gene with a major effect on the QTL on chromosome 6 affecting milk yield and composition in Holstein cattle. Genome Res. 15:936-944.

Druet, T., S. Fritz, D. Boichard, and J. J. Colleau. 2006. Estimation of genetic parameters for quantitative trait loci for dairy traits in the French Holstein population. J. Dairy Sci. 89:4070-4076.

Fernando, R. L., and M. Grossman. 1989. Marker assisted selection using best linear unbiased prediction. Genet. Sel. Evol. 21:467-477.

Georges, M., D. Nielsen, M. Mackinnon, A. Mishra, R. Okimoto, A. T. Pasquino, S. Sargeant, A. Sorensen, M. R. Steele, X. Zhao, J. E. Womack, and I. Hoeschele. 1995. Mapping quantitative trait loci controlling milk production in dairy cattle by exploiting progeny testing. Genetics 139:907-920.

Grisart, B., W. Coppieters, F. Farnir, L. Karim, C. Ford, P. Berzi, N. Cambisano, M. Mni, S. Reid, P. Simon, R. Spelman, M. Georges, and R. Snell. 2002. Positional candidate cloning of a QTL in dairy cattle: Identification of a missense mutation in the bovine DGAT1 gene with major effect on milk yield and composition. Genome Res. 12:222-231.

Guillaume, F., S. Fritz, D. Boichard, and T. Druet. 2008. Estimation by simulation of the efficiency of the French marker assisted selection program in dairy cattle. Genet. Sel. Evol. 40:91-102.

Kashi, Y., E. Hallerman, and M. Soller. 1990. Marker-assisted selection of candidate bulls for progeny testing programmes. Anim. Prod. 51:63-74.

Meuwissen, T. H. E., B. J. Hayes, and M. E. Goddard. 2001. Prediction of total genetic value using genome-wide dense marker maps. Genetics 157:1819-1829.

Pong-Wong, R., A. W. George, J. A. Woolliams, and C. S. Haley. 2001. A simple and rapid method for calculating identity-by-descent matrices using multiple markers. Genet. Sel. Evol. 33:453-471.

Robert-Granié, C., B. Bonaïti, D. Boichard, and A. Barbat. 1999. Accounting for variance heterogeneity in French dairy cattle genetic evaluation. Livest. Prod. Sci. 60:343-357.

VanRaden, P. M., and G. R. Wiggans. 1991. Derivation, calculation, and use of national animal model information. J. Dairy Sci. 74:2737-2746.

Visscher, P. M., and C. S. Haley. 1998. Strategies for marker assisted selection in pig breeding programmes. Commun. no. 23-503-510 in Proc. 6th World Congr. Genet. Appl. Livest. Prod., Armidale, Australia. L. Piper, ed. 